\title{
СТРАННАЯ РЕЦЕНЗИЯ
}

\section{ВЛАДИМИР ЛИТВИНЕНКО ${ }^{1, *}$}

\begin{abstract}
Статья представляет собой ответ на критические замечания Сергея Максудова «Больше или меньше?», опубликованные в Демографическом обозрении в 2015 году в адрес моей книги «Цена войны. Людские потери на советско-германском фронте», изданной в 2013 году.
\end{abstract}

Ключевые слова: Красная армия, вермахт, советско-германский фронт, оченки демографических и безвозвратных людских потерь.

Статья сотрудника Центра Российских и Евразийских исследований им. Дэвиса Гарвардского Университета (США) Сергея Максудова "Больше или меньше?" [Максудов 2015] - это вроде бы рецензия на мою книгу "Цена войны. Людские потери на советскогерманском фронте" [Литвиненко 2013]. Но рецензия какая-то очень странная.

\section{УДИВИТЕЛЬНОЕ НАЧАЛО И ПОРАЗИТЕЛЬНЫЙ ВЫВОД}

Удивляет, прежде всего, представление Максудова о задачах моей книги. Перечислив спекуляции, обозначенные в названиях параграфов пятой главы моей книги, Максудов пишет: “Для опровержения этих ошибочных утверждений Владимир Литвиненко тщуательно рассматривает несколько десятков оценок военных потерь, сделанных разными авторами, сопоставляя их с результатами статистического исследования коллектива военных ученых во главе с Г.Ф. Кривошеевым "Гриф секретности снят»" [Максудов 2015: 148]. Но на самом деле задачами моей книги (они перечислены в предисловии [Литвиненко 2013:4]) являются: 1) анализ и обобщение результатов оценок людских потерь на советско-германском фронте; 2) выявление реальных пределов соотношения потерь Красной армии и вермахта; 3) критика спекуляций на тему людских потерь Красной армии в Великой Отечественной войне. Ни одна из этих задач в рецензии Максудова не обсуждается.

Рецензированию подвергается, главным образом, материал лишь одного параграфа второй главы книги, в котором обсуждаются оценки людских потерь Красной армии коллектива под руководством Г.Ф. Кривошеева. Такой подход Максудова к рецензированию моей книги не вызвал бы возражений (рецензент волен выбирать любую часть или любой фрагмент книги для обсуждения), если бы не «глобальный» вывод его статьи: «Попытка В.В. Литвиненко разоблачить исследователей, результаты которых не совпадают с материалами [Гриф секретности... 1993], не удалась» [Максудов 2015:163].

\footnotetext{
1 АО «РОСОБОРОНЭКСПОРТ» (РОССИя).

*E-mail: vvlitv@yandex.ru

СТАТЬЯ ПОСТУПИЛА В РЕДАКЦИЮ В МАРТЕ 2016 Г.
} 
Этот вывод совершенно не соответствует содержанию статьи Максудова. Вопервых, в ней результаты исследований оппонентов Г.Ф Кривошеева - их суммарные оценки людских потерь Красной армии в Великой Отечественной войне - вообще не рассматриваются и не упоминаются. И о моей критике этих результатов в рецензии нет ни слова ${ }^{1}$. Во-вторых, вывод рецензии противоречит собственным утверждениям Максудова. Обсуждая число погибших в плену советских воинов (а это важная составляющая суммарных потерь Красной армии), он пишет: «Представляется справедливой критика Литвиненко сверхбольших потерь военнопленных (4 млн) по оценке В.Н. Земскова» [Максудов 2015:156]. Но ведь у двух из трех критикуемых мною наиболее агрессивных оппонентов Г.Ф Кривошеева оценки погибших военнопленных не меньше, чем у В.Н. Земскова, т.е. «сверхбольшие»: у Б.В. Соколова - 4 млн человек, а у И.И. Ивлева- 5,364 млн. [Литвиненко 2013: 63,73]. Если мою критику оценки В.Н. Земсковым потерь военнопленных Максудов называет справедливой, то и критику аналогичных оценок Б.В. Соколова и И.И. Ивлева тоже нужно признать справедливой, но об этом Максудов умалчивает.

\section{НЕВНИМАТЕЛЬНОСТЬ}

Что же касается критики Максудовым выбранных им фрагментов рецензируемых книг [Гриф секретности... 1993; Литвиненко 2013], то она не удалась. Большинство критических замечаний Максудова - результат недостаточно внимательного изучения им содержания рецензируемых книг ${ }^{2}$. Несколько тому примеров.

Начнем с терминологии. Максудов не различает содержание термина "безвозвратные потери" с демографической и с военно-оперативной точек зрения. Это различие подробно описано еще Б.Ц. Урланисом в книге, изданной в 1960 г. [Урланис 1960: 14-15]. Оно объяснено и в книге [Гриф секретности... 1993: 5, 129, 130], и в моей книге [Литвиненко 2013: 6-7]. С демографической точки зрения в безвозвратные потери включаются погибшие и умершие воины (в моей книге во избежание путаницы эти потери обозначены термином «демографические потери»). А с военно-оперативной точки зрения к безвозвратным потерям относятся не только погибшие и умершие воины, но и попавшие в плен и пропавшие без вести (в моей книге эти потери обозначены термином «безвозвратные потери») $)^{3}$. Результатом непонимания Максудовым указанного различия стал его ошибочный упрек Г.Ф. Кривошееву в занижении соотношения безвозвратных

\footnotetext{
1 Загадочна избирательность критики Максудова: вся она касается оценок демографических потерь Красной армии Г.Ф. Кривошеевым, максимальная из которых (9,2 млн человек [Кривошеев 1995:76]) отличается от собственной оценки Максудова (9,8 млн [Максудов 2015:158]) на 0,6 млн человек. Оценки же оппонентов Г.Ф. Кривошеева интереса у Максудова не вызвали, хотя их отличия от оценки Максудова значительно большие: оценка Л.Н. Лопуховского и Б.К. Кавалерчика (11,8 млн) - на 2 млн человек, И.И. Ивлева (20-21 млн) - на 10-11 млн человек, а Б.В. Соколова (26,9 млн) - на 17 млн человек [Литвиненко 2013: 73,114,128].

${ }^{2}$ Серьезного внимания заслуживает лишь замечание о некорректности подсчета численности эмигрантов из СССР в военное и послевоенное время.

${ }^{3}$ В моей книге в 14 таблицах, касающихся общих людских потерь и их соотношения, указываются значения и демографических, и безвозвратных потерь в военно-оперативном смысле [Литвиненко 2013: 71, 137 141, $149,150,156,168,180,184,192,201-203,207,217]$, но Максудов почему-то это не заметил.
} 
потерь. Максудов делит демографические потери Красной армии (8668 тыс. человек) на демографические потери фашистского блока (4918,3 тыс. человек) и получает соотношение 1,8:1 [Максудов 2015: 162], а у Г.Ф. Кривошеева соотношение потерь составляет 1,3:1. Но Г.Ф. Кривошеев оценивает соотношение не демографических, а безвозвратных потерь [Гриф секретности 1993: 392], поэтому делит безвозвратные потери Красной армии (11444 тыс. человек) на безвозвратные 4 потери фашистского блока (8649,5 тыс. человек) и получает соотношение $1,3: 1$.

Максудов оперирует странными цифрами потерь вермахта убитыми. Приведенной в книге [Гриф секретности 1993] численности погибших немецких военнослужащих на советско-германском фронте (2,8693 млн [Максудов 2015:161]) он, ссылаясь на книгу Б. Мюллера-Гиллебранда, противопоставляет цифру потерь вермахта убитыми на всех фронтах (2-2,3 млн), а в сноске утверждает, что Рюдигер Оверманс «относит к потерям на Восточном фронте убитыли всего 1135 тыс. плюс 465 mыс. (две трети от нерасчленненых потерь на Востоке и Западе)» [Максудов 2015:162]. Но эти сведения неверны: Б. Мюллер-Гиллебранд по поводу потерь вермахта писал следующее: «...можно оценить общие потери личного состава германских вооруженных сил числом, равныл 4 млн. убитыми...» [Мюллер-Гиллебранд 1976: 340], а Р. Оверманс оценивает потери вермахта на советско-германском фронте убитыми и умершими почти в 4 млн человек [Оверманс 1999: 265]. Эта оценка Р.Оверманса тоже есть в моей книге [Литвиненко 2013:164: таблица 3.4].

Максудов приписывает мне утверждение, которое мне не принадлежит. Он с сарказмом пишет: “По ходу расчета Литвиненко сделал следующее удивительное заявление: "Для корректного сравнения с оценками зарубежных исследователей к этой циифре надо добавить 500 тысяч погибших из числа призванных, но захваченных немцами до прибытия в войска военнообязанных» [Литвиненко 2013]. Речь идет все о тех же злополучных несостоявшихся красноармейцах, которые мало того, что практически в каждом расчете играют важную роль, мало того, что все до единого, не дойдя до воинской части, оказались в плену, но оказывается им и там не повезло, все без исключения в плену и погибли” [Максудов 2015: 156]. На самом деле утверждение о «500 тысяч погибших из числа призванных, но захваченных немцами до прибытия в войска военнообязанных» принадлежит Г.Ф. Кривошееву, и приведено оно в цитируемой Максудовым работе, опубликованной в сборнике «Людские потери СССР в Великой Отечественной войне» [Кривошеев 1995]. Вот что по этому поводу сообщил Г.Ф. Кривошеев: «11944100 чел. составили безвозвратные потери, в том числе 11444100 чел. списочного состава, 500 тыс. чел. военнообязанных, не дошедших до частей и не попавших в списки». Далее он определяет демографические потери: «...Таким образом фактическое число демографических потерь составляет 11944100-2775700 (939,7 mblc. +1836 mblc.) $=$

4 Г.Ф. Кривошеев специально оговаривает [Гриф секретности... 1993: 385] содержание термина «безвозвратные потери вермахта»: «Безвозвратные потери включают убитых, умерших от ран и болезней в лечебных учреждениях и на дому по причинам, связанным с применением боевых средств, пропавших без вести, а также небоевые потери (погибшие при несчастных случаях, происшествиях, расстреляннье и т.п.). В отчетных документах вермахта нет такой категории, как пленные. Они учитываются по разделу "без вести пропавшие». 
9168400 чел. Из них: списочного состава - 8 млн. 668 тыс. 400 чел.; не попавших в список - 500 mblc. чел.» [Кривошеев 1995: 76]. Впрочем, авторство обсуждаемой фразы не столь уж важно, важно другое: Максудов не сумел разобраться в причинах ее появления. Дело в том, что число погибших в плену Г.Ф. Кривошеев определял балансовым методом, особенностью которого является то, что изменение одной составляющей баланса автоматически вызывает изменение других составляющих и (или) их суммы. Включение Г.Ф. Кривошеевым в безвозвратные потери 500 тыс. призванных, но не попавших в списки войск, автоматически увеличило на эту цифру число погибших в плену (с 1,773 до 2,273 млн человек), потому что число выживших пленных и пропавших без вести осталась неизменным - 2775700 человек. Это увеличение числа погибших в плену затронуло две составляющие баланса, относящиеся к категории пропавших без вести: 500 тыс. призванных, но не попавших в списки войск, и 500 тыс. пропавших без вести, но не оказавшихся в плену. В реальности в плену погибли не все призванные, но не попавшие в списки войск, а какая-то часть, а недостающая до 500 тыс. часть приходится на пропавших без вести, но не оказавшихся в плену. Если, например, погибло в плену 300 тыс. призванных, но не попавших в списки войск, то 500 тыс. погибших в плену получается, если число пропавших без вести, но не оказавшихся в плену, будет не 500 тыс., а 300 тыс. человек. Проблема в том, что неизвестно число погибших в плену из 500 тыс. призванных, но не попавших в списки войск (их, может быть, было 200 тыс., 300 тыс., а может, больше или меньше). Соответственно неизвестно, на сколько нужно сократить число пропавших без вести, но не оказавшихся в плену. Поэтому Г.Ф. Кривошеев, чтобы не запутывать и без того не простое положение с числом погибших из числа пропавших без вести и попавших в плен, упростил ситуацию, засчитав погибшими в плену все 500 тыс. призванных, но не попавших в списки войск.

Невнимательным прочтением моей книги объясняется утверждение Максудова о постоянно приводимых мною аргументах: «...Критикуя множество оппонентов Кривошеева, Литвиненко пользуется постоянно одним и тем же набором аргументов: 1) в численность армий и фронтов, приводимых Кривочеевым, включены не все части, некоторые (меньше дивизии) пропущены; 2) не все мобилизованные попадали на фронт, некоторые отправлялись на работу в промышленность или в войска НКВД; 3) не все воевавшие были красноармейцами списочного состава; 4) маршевые пополнения не всегда добирались до боевых частей» [Максудов 2015: 151]. В действительности перечисленные аргументы использовались при обсуждении оценок потерь Г.Ф. Кривошеевым, а критика оценок его оппонентов производилось с помощью совсем других аргументов. Оценки Б.В. Соколова, подсчитавшего потери Красной армии путем экстраполяции потерь в ноябре 1942 г. на 46 месяцев войны, основаны на принципиально непригодном применении линейной экстраполяции к сугубо нелинейным явлениям, какими являются людские потери в войне, а также на умышленной подтасовке исходных данных, ошибках подсчетов потерь по потерям офицерского состава, по балансу всего населения, по балансу мужского населения страны и по данным ОБД "Мемориал" [Литвиненко 2013:71-105]. В оценках И.И. Ивлева обнаружен двойной счет потерь, неучет "естественной" смертности в оценках потерь по балансу населения, ошибки при подсчетах потерь по данным ОБД "Мемориал" и по балансу вооруженных сил [Ивлев 2012: 335-341; Литвиненко 2013:105-127]. Л.Н. Лопуховский и Б.К. Кавалерчик недостаточно четко понимают границы исследования 
Кривошеева Г.Ф., а их оценки ошибочны из-за двойного счета потерь [Литвиненко 2013: 128-130].

\section{НЕУДАЧНАЯ КРИТИКА}

Замечания Максудова, касающиеся обсуждения мною претензий оппонентов к оценкам Г.Ф. Кривошеева, относятся к Московской оборонительной операции и числу советских военнопленных. Эти замечания - тоже плоды невнимательного отношения Максудова к содержанию рецензируемых книг. Максудов неверно трактует мои аргументы. В книге претензии оппонентов к Г.Ф. Кривошееву обсуждаются в рамках решения задачи анализа и обобщения результатов оценок людских потерь на советско-германском фронте, т.е. рассматриваются с позиции их влияния на итоговую оценку потерь Красной армии в войне - нуждается ли она в корректировке? Обсуждение заканчивается таблицей 2.7, содержащей обобщенные по результатам обсуждения интервальные оценки людских потерь Красной армии на советско-германском фронте по данным списочного учета [Литвиненко 2013: 7071]. Максудов же рассматривает претензии к Г.Ф. Кривошееву по поводу потерь в Московской оборонительной операции изолированно, без привязки к итоговой оценке потерь Красной армии. Поэтому Максудов не обратил внимания на фразу в моей книге: «Поскольку общие безвозвратные потери Красной армии по состоянию на 1 марта 1942 2. подсчитаны Кривошеевым Г.Ф в цеелом правильно (цифры согласуются со сведениями справки организационно-учетного отдела Оперативного управления Генерального штаба от 1 марта 1942 г. - В.Л.), то даже если потери фронтов на московском направлении несколько занижены, то это компенсировано некоторым завышением потерь на других фронтах» [Литвиненко 2013: 43]. Именно соответствие цифры общих безвозвратных потерь Красной армии, подсчитанной Г.Ф. Кривошеевым, сведениям официального документа Генерального штаба РККА на 1 марта 1942 г. не позволяет без дополнительных исследований потерь на всех фронтах в октябре 1941 г. скорректировать итоговую цифру потерь Красной армии за счет увеличения потерь в Московской оборонительной операции 5 .

Не понял Максудов, что переход к относительным величинам, над которым он иронизирует [Максудов 2015: 154-155], мною был сделан не ради математических игр, а с целью противодействия попыткам оппонентов Г.Ф. Кривошеева «гиперболизировать» неточности и некорректности его подсчетов. А такие попытки были предприняты сразу же

\footnotetext{
5 Кстати, если пользоваться сведениями, приводимыми Максудовым, то с точки зрения войны в целом, занижение потерь Г.Ф. Кривошеевым было значительно меньше, чем определено в моей книге. Максудов, соглашаясь с оценкой занижения Г.Ф. Кривошеевым безвозвратных потерь Красной армии в Московской оборонительной операции в 340 тыс. человек [Максудов 2015: 155], к числу безвозвратных потерь причисляет 175 тыс. ушедших в партизаны, пробившихся из окружения, но не возвращенных в свои части, дезертировавших [Максудов 2015: 153]. Перечисленные категории военнослужащих для Московской битвы, безусловно, были безвозвратными потерями. Но для войны в целом - это возвратные потери: они были вновь призваны в армию после освобождения оккупированных территорий. Если к этим категориям военнослужащих добавить вышедших из Вяземского и Брянского котлов в ноябре-декабре 1941 г., а также отошедших в полосу соседнего Юго-Западного фронта, то суммарное число дополнительно вернувшихся в строй из Вяземского и Брянского котлов советских солдат составит более 200 тыс. "Занижение" потерь Г.Ф. Кривошеевым при этом будет не 200 тыс. человек, как прогнозировалось в моей книге, а в 2 раза меньше чуть более 100 тыс.
} 
после выхода книги [Гриф секретности...1993] и продолжаются до сих пор. Так, в моей книге [Литвиненко 2013:36] показано, что «вывод» о якобы «занижении» Г.Ф. Кривошеевым в 3 раза суммарных потерь Красной армии в войне сделан Б.В. Соколовым на основе примеров, абсолютные цифры "недоучета" потерь (причем подсчет сделан с ошибками [Литвиненко 2013:27-35]) составляли менее 0,5\% от официального числа безвозвратных потерь Красной армии.

Неудачным получилось возражение Максудова на мнение историка К. Рейнгардта о том, что «...Бои в Брянском котле не принесли немщам желаемого успеха» [Литвиненко 2013:40]. Максудов на это мнение отреагировал так: «Желаемый успех принесли немцам танки 2-й армии генерала Гудериана, которые, действуя на южном крыле наступающей немечкой армии, 3 октября захватили город Орел, 6 октября ударом с востока - Брянск, 10 октября подошли к Туле...» [Максудов 2015:152]. Но мнение генерал-полковника вермахта Гейнца Гудериана о боях в октябре 1941 г. не столь благостно. В своих мемуарах Г. Гудериан писал: «...Тяжесть боев постепенно оказывала свое влияние на наших офицеров и солдат. ...На поле боя командир дивизии (4-й танковой - В.Л.) показал мне результаты боев 6 и 7 октября, в которых его боевая группа выполняла ответственные задачи. Подбитые с обеих сторон танки еще оставались на своих местах. Потери русских были значительно меньше наших потерь...Возвратившись в Орел, я встретил там полковника Эбербаха ...Впервые со времени начала этой напряженной кампании у Эбербаха был устальй вид, причем чувствовалось, что это не физическая усталость, а душевное потрясение. Приводил в смущение тот факт, что последние бои подействовали на наших лучших офицеров. Но зато в главном командовании сухопутных войск и в штабе группь армий изарило приподнятое настроение! Именно в этом проявилась пропасть между взглядами высшего командования и нашими, хотя в тот период 2-я танковая армия ничего не знала о том, что высшее командование так сильно опьянено нашими победами...» [Гудериан 2001: 317-318].

Теперь о советских военнопленных. О них Максудов тоже рассуждает в общем плане, без привязки к итоговой цифре потерь Красной армии в войне. Он пишет, что до эмиграции из СССР он считал, что численность советских военнопленных была 4,3 млн, но попав на Запад, изменил свои взгляды, согласившись с цифрой западных историков - 5,7 млн попавших в плен советских воинов [Максудов 2015: 157] ${ }^{6}$. На мой взгляд, Максудов поторопился со сменой мнения. Цифра плененных немцами военнослужащих - именно военнослужащих, а не всех, кого немцы брали в плен, - значительно меньше 5,7 млн. Здесь следует отметить четыре обстоятельства. Во-первых, расхождения в оценках относятся, главным образом, к числу плененных в 1941 г. советских воинов. Объясняется это тем, что в 1941 г. учет советских военнопленных в вермахте не был налажен. Представление донесений о числе военнопленных в штабы вермахта было не обязательным

\footnotetext{
${ }^{6}$ И здесь какие-то странности. Максудов сообщает, что его новые цифры советских военнопленных и погибших среди них (5,7 и 3 млн соответственно) были опубликованы в книге, датируемой 1989 г. [Максудов 2015: 157]. Но 4 года спустя в статье "О фронтовых потерях Советской армии во Второй мировой войне" [Максудов 1993: 118-119] он помещает прежние цифры (4,3 и 1,2 млн соответственно). Выходит, что в 1993 г. Максудов вернулся к первоначальным оценкам потерь Красной Армии пленными, а сейчас снова изменил свое мнение.
} 
(соответствующее распоряжение было отдано войскам лишь в январе 1942 г.). С июля 1941 г. учет советских военнопленных велся отделом по учету военнопленных генерального штаба вермахта (ОКВ), но это касалось лишь военнопленных, находившихся на территории рейха [Великая Отечественная... 2009: 320-321]. Число советских военнопленных, находившихся в 1941 г. на оккупированных территориях, оценивается западными исследователями по донесениям немецких войск. Эти данные не могут считаться достоверными, так как имеется много свидетельств о стойкой практике завышения в донесениях немецких войск потерь противника, о чем, кстати, сообщает сам Максудов [2015: 156]. Во-вторых, западные исследователи и Максудов вместе с ними не учитывают, что среди советских военнопленных было много гражданских лиц, о чем сообщали немецкие чиновники во время войны и пишет немецкий историк Кристиан Шрайт (эти сведения приведены в моей книге [Литвиненко 2013: 49,54]). В-третьих, сведения Г.Ф. Кривошеева о попавших в плен и пропавших без вести советских военнослужащих в 1941 г. соответствуют балансу численности действующей армии с 22.06.1941 по 01.01.1942 г. [Литвиненко 2013: 50-51], а сведения Г.Ф. Кривошеева о безвозвратных потерях Красной армии за первый год войны хорошо согласуются с данными справки организационноучетного отдела Оперативного управления Генерального штаба и доклада начальника Главного управления по формированию и укомплектованию войск Красной армии генералполковника Е.А. Щаденко о мобилизационных ресурсах и их использовании за год войны [Михалев 2000: 98-107]. Наконец, в-четвертых, современные немецкие историки ревизионистского направления считают, что и численность, и число погибших советских военнопленных на территории рейха, указанные после войны в различных источниках, были завышены [Ерин 2005: 132-134]. Пока не будут прояснены перечисленные обстоятельства, нет оснований для пересмотра в сторону повышения цифр Г.Ф. Кривошеева, относящихся к числу советских военнопленных из списочного состава Красной армии. Отмечу, что приведенная выше аргументация имеется в книге [Литвиненко 2013: 49-55], но Максудов ее, видимо, не заметил.

Если Максудов принимает цифру Г.Ф. Кривошеева о попавших в плен и пропавших без вести в 5,059 млн человек [Максудов 2015: 157], то цифра погибших в плену получается совсем не похожей на ту, которую он обсуждает (1,103 млн.) [Максудов 2015: 155, 157]. ${ }^{7}$ Число погибших в плену при 5,059 млн человек попавших в плен и пропавших без вести рассчитывается следующим образом.

Общее число погибших в плену и пропавших без вести советских военнослужащих - 5,059 млн (в том числе 0,5 млн мобилизованных, но пропавших без вести, не дойдя до войск) [Великая Отечественная... 2009: 323-324]. Из них:

- пропавшие без вести, но не оказавшиеся в немецком плену - 0,5 млн,

- находились в плену - 4,559 млн,

- вернулись из плена по репатриации -1,836 млн,

\footnotetext{
${ }^{7}$ Справедливости ради нужно сказать, что разнобой в оценках числа погибших в плену явился следствием нечеткости и противоречивости оценок Г.Ф. Кривошеева этой категории потерь, в том числе из-за расплывчатости и запутанности статуса злополучных 500 тыс. человек, отнесенных к потерям гражданского населения.
} 
- повторно призванные после освобождения оккупированных территорий - 0,9397 млн,

- эмигрировавшие в другие страны - 0,2 млн.

Множества репатриированных и вновь призванных являются пересекающимися: они имеют общую часть - 0,2281 млн человек, которые, по данным В.Н. Земскова [1995:11], входили как в число репатриированных военнопленных, так и в число вновь призванных в армию с освобожденных оккупированных территорий. Это значит, что общее число репатриированных и вновь призванных равно:

$$
1,836+0,9397-0,2281=2,5556 \text { млн. }
$$

Тогда число погибших советских военнопленных равно:

$$
4,559-2,555-0,2=1,8034 \text { млн. }{ }^{8}
$$

Именно эта цифра (1,8 млн) погибших в плену учтена в итоговой таблице 2.7 моей книги [Литвиненко 2013:70-71].

А подмеченная Максудовым якобы «противоречивая» цифра в 1,1033 млн погибших в плену солдат списочного состава [Максудов 2015: 156] появилась в тексте моей книги лишь при обсуждении подсчетов погибших в плену Л.Н Лопуховским и Б.К. Кавалерчиком, поскольку в своем балансе они разделили пленных и пропавших без вести: пропавшие без вести были выделены в отдельную строку баланса [Литвиненко 2013:128]. Но, как было показано выше, 500 тыс. из пропавших без вести также погибли в плену.

\section{ДВОЙНЫЕ СТАНДАРТЫ И СОФИЗМЫ}

Максудов, видимо, понимая неубедительность своих критических замечаний, пытается их «усилить». Это «усиление» вольно или невольно приняло формы пресловутых «двойных стандартов» и софизмов.

Примером «двойных стандартов» служит странное для научного работника выделение Максудовым в качестве «серьезного недостатка» исследования Г.Ф. Кривошеева и моей книги [Гриф секретности...1993; Литвиненко 2013] «желание ограничиться только списочнылм составом армии» [Максудов 2015:149]. Между тем непременной частью любого исследование является определение его границ. И такие границы в книгах [Гриф секретности...1993; Литвиненко 2013] четко обозначены: оцениваются лишь потери списочного состава Красной армии и вермахта. В подобных границах, например, провел исследования бывший начальник организационного отдела генерального штаба сухопутных войск вермахта генерал-майор Б. Миллер-Гиллебранд, которого Максудов относит к числу «серьезных западных ученых». В своем труде Б. Мюллер-Гиллебранд подсчитал лишь потери вермахта, а потери «фольксштурма»,

\footnotetext{
${ }^{8}$ Доля погибших военнопленных в 1941 г. тоже получается не той, что подсчитал Максудов [2015: 157]. Если принять долю погибших в 1941 г. равной двум третям от общего числа погибших военнопленных (так считает Максудов), то это составит 1,2 млн. Поскольку в 1941 г., по данным Г.Ф. Кривошеева, попали в плен и пропали без вести 2,335 млн человек [Кривошеев 1993: 146-147], то смертность советских военнопленных в 1941 г. составляла более 51\%, а не 25\%, как определил Максудов [2015: 157].
} 
«вервольфа», «гитлерюгенда»и других вооруженных формирований, не входивших в вермахт, он не оценивал [Мюллер-Гиллебранд 1976]. Но к Б. Мюллеру-Гиллебранду у Максудова претензий нет.

Для усиления эффекта Максудов сопровождает упомянутую претензию еще и эмоциональным упреком: «...Столкнувшись с более высокими оценками убитых или военнопленных, Кривошеев и Литвиненко тут же объявляют, что в них, вероятно, учтень не только зарегистрированные красноармейцы, но и ополченцы, сотрудники милиции, партизаны, железнодорожники, строчтели оборонительных сооружений и прочие гражданские лица. Сколько было их «званных, но не призванных», авторы не знают, и главное, это их совершенно не интересует (выделено мной - В.Л.). Такой подход представляется неверным. Все, кто взял в руки оружие и боролся с врагом, были защитниками родины, бориами с фашизмом, героями, память о каждом из них необходимо сохранить, их участие в сражениях должно быть зафиксировано. Исключение этих людей из тех или иных рядов, отсутствие интереса к ним будет нарушением правды о Великой Отечественной войне, о реальных потерях нашего народа в этой битве» [Максудов 2015: 149]. Подобные упреки в логике квалифицируются как умышленные уловки (софизмы), называемые «аргументом к публике» [Ивлев 1992: 214] (в данном случае - воздействие на чувства читателей).

К двойным же стандартам относится и замечание Максудова: «Оцеенка потерь Германии не нуждается в “помощчи” советских историков» [Максудов 2015: 161] 9 . Но при оценке потерь СССР, в частности военнопленными, Максудов не только обращается к "помощи" западных историков, но и считает достоверными лишь их данные.

Раздел «Сравнение немецких и советских военных потерь» статьи Максудов начинает фразой: «Завершив разоблачение разнообразных критиков Кривошеева $и$ Андреева с соавторами, Литвиненко переходит $\kappa$ рассмотрению потерь Вермахта $u$ соотношения потерь на советско-германском фронте» [Максудов 2015: 160]. Но в дальнейшем тексте статьи вообще ничего (ни слова!) из моего «рассмотрения потерь Вермахта и соотношения потерь на советско-германском фронте» не упоминается, а критикуются (причем, неверно) подсчеты книги [Гриф секретности...1993]. Такое изменение предмета обсуждения в логике называется "логической диверсией" [Ивлев 1992: $210]$.

\section{ЗАКЛЮЧЕНИЕ}

Рецензия Сергея Максудова на мою книгу не получилась. Не поняв целевых установок книги, Максудов, не замечая «бревен» ошибок других исследователей, зациклился на

\footnotetext{
9 Этот тезис Максудов мотивирует тем, что после войны для ученых были открыты немецкие военные архивы. Но, видимо, Максудов не знает, что немецкие архивные документы о потерях вермахта характеризуются неполнотой и недостаточной достоверностью. Неполнота объясняется тем, что значительная часть архивных документов вермахта находится в других странах, в том числе в России (кроме того, большое число документов было уничтожено и утеряно в конце войны). А недостоверность архивных документов о потерях вермахта подробно обсуждается в книге Р. Оверманса [Overmans 1999].
} 
«соломинках» недостатков как исследования Г.Ф. Кривошеева, так и моих доводов в его пользу. Но и в этом он не преуспел в силу невнимательного отношения к содержанию рецензируемых книг и неверной интерпретации приводимых в них аргументов.

Разумеется, книга [Гриф секретности... 1993] не лишена недостатков. В ней (и в ее последующих изданиях) есть и нестыковки в цифрах, и в их интерпретации, и некорректности, и неточности, и противоречия, и другие ошибки ${ }^{10}$. В работах подобного масштаба погрешности неизбежны. Здесь важен уровень этих погрешностей. Анализ результатов статистического исследования и их проверка балансовыми методами показывает, что погрешность подсчетов потерь Красной армии на советско-германском фронте авторским коллективом под руководством Г.Ф. Кривошеева не превышает несколько сотен тысяч человек. Погрешности же альтернативных подсчетов потерь Красной армии на порядок выше: у Л.Н. Лопуховского и Б.К. Кавалерчика погрешность в несколько миллионов человек, у И.И. Ивлева она достигает 8 млн человек, а у Б.В. Соколова ошибка превышает 2 десятка миллионов человек. Кроме того, бесстрастный исторический опыт войн доказывает правоту расчетов авторского коллектива Г.Ф. Кривошеева. Результаты войн последних двух столетий показывают, что о многократном превышении потерь Красной армии над потерями вермахта на советско-германском фронте и речи не может быть: Красная армия была бы не в состоянии победить вермахт даже, если бы ее безвозвратные потери превышали безвозвратные потери немецких войск более чем в 1,5 раза. Утверждения о том, что «Великая Победа была одержана цееной невероятно высоких и неоправданных потерь» [Соколов 2005], что «людские потери, которые понесла Красная армия в Великой Отечественной войне, многократно превысили потери вермахта» [Надеждин 2005], относятся к области ненаучной фантастики.

\section{ЛИТЕРАТУРА}

Великая Отечественная без грифа секретности. Книга потерь (2010) / Под ред. Г.Ф. Кривошеева, В.М. Андронникова, П.Д Бурикова, В.В. Гуркина. М.: Вече. 384 с.

Гриф секретности снят. Потери вооруженных сил СССР в войнах, боевых действиях и военных конфликтах (1993) // Под. ред. Г.Ф. Кривошеева. М: Воениздат. 370 с.

Гудериан Г. (1999). Воспоминания солдата. Пер. с немец. Смоленск: Русич. 654 с.

Ерин М.Е. (2005). Советские военнопленные в нацистской Германии 1941-1945 гг. Проблемы исследования. Ярославль: ЯрГУ. 178 с.

Земсков В.Н. (1995). Репатриация советских граждан и их дальнейшая судьба // Социологические исследования. 5: 3-13.

Ивлев И.И. (2012). «... А в ответ тишина - он вчера не вернулся из боя!» // сб. Умылись кровью? М.: Яуза. Эксмо: 260-509.

Ивлев Ю.В. (1992). Логика. М.: Изд-во Моск. ун-та.

10 Часть неточностей, ошибок и противоречий книги Г.Ф. Кривошеева [Гриф секретности...1993] рассмотрены в моей книге [Литвиненко 2013: 61, 69,70, 168]. 
Кривошеев Г.Ф. (1995). Об итогах статистических исследований потерь Вооруженных Сил СССР в Великой Отечественной войне // Людские потери СССР в Великой Отечественной войне. Санкт-Петербург.

Литвиненко В.В. (2013). Цена войны. Людские потери на советско-германском фронте. М.: Вече. 288 c.

Максудов С. (1993). О фронтовых потерях Советской армии в годы Второй мировой войны // Свободная мысль. 10: 117-119.

Максудов С. (2015). Больше или меньше? // Демографическое обозрение. 2 (1): 148-165. URL: https://demreview.hse.ru/2015--1/163584304.html (дата обращения: 10.01.2016).

Михалев С.Н. (2000). Людские потери в Великой Отечественной войне 1941-1945 гг. Статистическое исследование. Красноярск: РИО КГПУ.

Мюллер-Гиллебранд Б. (1976). Сухопутная армия Германии 1933-1945 гг. Т.3. Война на два фронта. Пер. с немец. М.: Воениздат. 416 с.

Надеждин И. (2005). Потерянные миллионы // Итоги. 19.

Соколов Б.В. (2005). Цена победы и мифы Великой Отечественной // Великая война: трудный путь к правде. Интервью, воспоминания, статьи. Серия «АИРО»-научные доклады и дискуссии. Вып. 17: 53-71.

Урланис Б.Ц. (1960). Войны и народонаселение Европы. Людские потери вооруженных сил европейских стран в войнах XVII - XX вв. (Историко-статистическое исследование). М.: Соцэкгиз. 568 с.

Overmans R. (1999). Deutsche Militarische Verluste im Zweiten Weltkrieg. Munchen: R. Oldenbourg Verlag. 


\section{STRANGE REVIEW}

\section{VLADIMIR LITVINENKO ${ }^{1, *}$}

The article is a response to S. Maksudov's criticism "More or less?", which was published in "Demographic Review" in 2015 with regards to my book "The price of war. Casualties on the Soviet-German front" (2013).

Key words: Red Army, vermacht, Soviet-German front, estimates of demographic and irrevocable human losses.

\footnotetext{
${ }^{1}$ ROSOBORONEXPORT (RUSSIA).

* CoRrespondence: vvlitv@yandex.ru.

DATE RECEIVED: MARCH 2016.
}

\section{REFERENCES}

Erin M.E. (2005). Sovetskie voennoplennye v nacistskoj Germanii 1941-1945 gg. Problemy issledovaniya [Soviet prisoners of war in Nazi Germany 1941-1945. Research problems]. Yaroslavl: YarGU. 178 p.

Grif sekretnosti snyat. Poteri vooruzhennykh sil SSSR v voynakh, boyevykh deystviyakh i voyennykh konfliktakh [Secrecy label removed. Casualties of the armed forces of the USSR in wars, hostilities and military conflicts] (1993). G.F.Krivosheev, ed. Moscow: Voenizdat. $370 \mathrm{p}$.

Guderian G. (2001). Vospominaniya soldata [Memories of a soldier]. Smolensk: Rusich.

Ivlev I.I. (2012). «... A v otvet tishina - on vchera ne vernulsya iz boya!» [... Silence as a response - yesterday he did not return from the battle!] // sb. Umylis' krov'yu? [Bloody war] Moscow: Yauza. Eksmo: 260-509.

Ivlev Yu.V. (1992). Logika. Uchebnik [Logic. Textbook]. Moscow: Izd-vo Mosk. un-ta. 270 p.

Krivosheev G.F. (1995). Ob itogah statisticheskih issledovanij poter' Vooruzhennyh Sil SSSR v Velikoj Otechestvennoj vojne [On the results of statistical researches concerning the losses of the Soviet armed forces in the Great Patriotic War] // Lyudskie poteri SSSR v Velikoj Otechestvennoj vojne [Casualties of the USSR in the Great Patriotic War]. Saint Petersburg.

Litvinenko V.V. (2013). Cena vojny. Lyudskie poteri na sovetsko-germanskom fronte [The price of the war. Casualties on the Soviet-German front]. Moscow: Veche. 288 p.

Maksudov S. (1993). O frontovyh poteryah Sovetskoj armii v gody Vtoroj mirovoj vojny [The Soviet army front losses in the World War II] // Svobodnaya mysl' [Free thought]. 10: 117119.

Maksudov S. (2015). Bol'she ili men'she? [More or less?] // Demograficheskoe obozrenie [Demographic review]. 2 (1): 148-165. URL: https://demreview.hse.ru/2015-1/163584304.html (accessed: 10.01.2016).

Mikhalev S.N. (2000). Lyudskie poteri v Velikoj Otechestvennoj vojne 1941-1945 gg. Statisticheskoe issledovanie [Casualties in the Great Patriotic War 1941-1945. Statistical research]. Krasnoyarsk: RIO KGPU.

Mueller-Gillebrand B. (1976). Suhoputnaya armiya Germanii 1933-1945 gg. T.3. Vojna na dva fronta [German land force 1933-1945. Vol.3. Two-front war]. Moscow:Voenizdat. 416 p. 
Nadezhdin I. (2005). Poteryannye milliony [Lost millions] // Itogi [The outcome]. 19.

Overmans R. (1999). Deutsche Militarische Verluste im Zweiten Weltkrieg. Munchen: R. Oldenbourg Verlag.

Sokolov B.V. (2005). Cena pobedy i mify Velikoj Otechestvennoj [The price of the victory and myths of the Great Patriotic War] // Velikaya vojna: trudnyj put' k pravde. Interv'yu, vospominaniya, stat'i [The Great War: a difficult way to truth. Interviews, memories, articles]. Seriya "AIRO" - nauchnye doklady i diskussii [AIRO - scientific reports and discussions]. Vyp. [Issue] 17: 53-71.

Urlanis B.Ts. (1960). Vojny i narodonaselenie Evropy. Lyudskie poteri vooruzhennyh sil evropejskih stran v vojnah XVII - XX vv. (Istoriko-statisticheskoe issledovanie) [Wars and European population. Casualties of the armed forces of the European countries in wars of XVII - XX centuries]. Moscow: Sotsekgiz. 568 p.

Velikaya Otechestvennaya bez grifa sekretnosti. Kniga poter' [The Great Patriotic War without secrecy label. The book of losses] (2010) / G.F. Krivosheev, V.M. Andronnikov, P.D Burikov, V.V. Gurkin, eds. Moscow: Veche. 384 p.

Zemskov V.N. (1995). Repatriaciya sovetskih grazhdan i ih dal'nejshaya sud'ba [Repatriation of Soviet citizens and their further destiny] // Sociologicheskie issledovaniya [Sociological Research]. 5: 3-13. 